\title{
Survey of Insects and Other Arthropods in Tomato (Lycopersiconesculentum Mill.) in Lanaodel Sur Province, ARMM, Philippines
}

\begin{abstract}
This study was conducted to identify the insects and other arthropods associated with tomato. Insects on tomato belong to 14 families under six orders. Tomato insects were classified under orders Coleoptera, Diptera, Hemiptera, Homoptera, Lepidoptera, and Hymenoptera. The insect pests included the leafminer, Liriomyza sp., aphids, Aphis gossypii, cutworm, Spodopteralitura, tomato fruitworm, Helicoverpaarmigera, cabbage looper, Trichoplusiani, flea beetle, Psylliodessp, ladybird beetles like the 12-spotted and 28-spotted ladybird beetles, Epilachnachrysomelina and Epilachnaphilippinenesis, squash beetle, Aulacophorasimilisandmelon fly, Bactroceracucurbitae. Beneficial species were bees (Apis sp.), braconid wasp (Cotesia sp.) and spiders. The survey started from December 14, 2013 and it ended on February 16, 2014.
\end{abstract}

Balabag, Nelson M. ${ }^{1}$, Anub, Remedios R. ${ }^{2}$ and Sabado, Emma M. ${ }^{3}$

Keywords: Tomato, insects, arthropods

\section{Introduction}

Tomato, Lycopersiconesculentum Mill., is one of the leading vegetable crops in the Philippines both in terms of hectarage and volume in production (Bas, 1997). The demand for this crop year-round owes to the versatility of its usage in both fresh and processed food preparation (Aganon et al., 2002). However, many arthropod pests will attack tomatoes, including arthropod-vectored diseases. Wakil, Brust, and Perring(2017) pointed out that sustainable management of arthropod pests of tomato is very important in tomato farming particularly in the application of pesticides and other alternative methods of pest management.

Tomato is cultivated in a wide range of environment by many farmers as cash crops. According to Talekar (1998)) all parts of tomato plant could serve as reproduction sites for the pest and even provide food and shelter for the pests. The existence of pest in the tomato plant will cause reduction of growth that lead to plant death by feeding and transmitting diseases caused by viruses and mycoplasma. Furthermore, insects in tomatoes will damage its fruits may in a form of fruit scaring, destruction of tissues and aberrations of shape. Gil (2015), mentioned that most cultivars of tomatoes are susceptible to a wide range of arthropods pest and the use of chemicals such as pesticides is not advisable due to its negative impact on the environment. G. S. Kund W. G. Carson J. T. Trumble (2015) offers the same view regarding the susceptibility of tomato on pest attacks. They said that when the pest attacks tomato, damages will be throughout the crop cycle. Pest management and control should be carried out carefully by using insecticides and chemical acaricide. But, this chemical pest will cause severe damage to the environment, biological imbalances, production costs, and deleterious effects on farmers and consumers health.

Several studies had been conducted about tomato farming particularly on pest prevention and management. One study is on the diversification of the agroecosystem. This diversification of the tomato agroecosystem may reduce insect pest infestation using the strategy of companion planting. However, the study concluded that environmental management to minimize the problems caused by the diseases of the tomato still remains to be studied (HorticulturaBrasileira, 2009). Study conducted by Talekar (1998) on the tomato agroecosystemfound out that few major key pests but more minor ones are usually present while other economically important crops, none of the insects are specific to tomato. Furthermore, there is a low acceptability of tomato as a host is assumed to be due to the presence of secondary plant metabolites, some of which have antibiotic effects on certain arthropods.

According to Morandina, Long and Kremena (2014), there are some techniques that could enhance the tomato growth and aid pest control, one of them is the hedgerows. Beneficial insects on adjacent tomato fields will be enhance through hedgerow and at the same time enhance an intensive agricultural landscape. Farm-scale 
hedgerows can provide 100 to $200 \mathrm{~m}$ pest control benefits in the fields while using multiple hedgerows enhance pest control in the entire field thereby reducing the use of chemical for pest control.

The quality of tomato is important in the market both processed and fresh market tomatoes. To maintain good quality of tomato fruits, quality control and pest management is essential. In any pest management program, proper identification of the pests must be done first before effective control measures can be implemented. However, data on insect pests that attack tomato is not yet available in Lanao del Sur Province, ARMM hence this study was conducted.

\section{Objectives of the Study}

1. To conduct a survey of insects and other arthropods associated with tomato in Lanao del Sur, ARMM;

2. To identify the major insect pests of tomato including their natural enemies.

\section{Materials and Methods}

\section{Place and Duration of the Study}

Survey of the insect pests and other arthropods associated with tomato was conducted at the experimental area of the College of Agriculture, Mindanao State University, Marawi City from December 14, 2013 to February 16, 2014.

\section{Collection of Insects and Other Arthropods}

Insects and related arthropods were collected through weekly visual sampling and sweeping. Leaves, stems and fruits of tomatoes were also examined closely. Collected specimens were preserved in vials filled with $80 \%$ of ethyl alcohol for proper identification.

Damaged fruits were collected and brought to the laboratory to allow the emergence of insects that attacked them. They were placed in closed containers to prevent the escape of the insects. The population of the different insects and other arthropods associated with tomato were monitored weekly until harvesting. Insects that caused the greatest damage to tomatoes were categorized as the major pests while those that caused less damage were considered as the minor pests. Collected insects were identified by Dr. Myrna Ballentes, an insect taxonomist from the Department of Entomology, Central Mindanao University (CMU), Musuan, Bukidnon.

\section{Results and Discussion}

\section{Insects and Other Arthropods Associated with Tomatoes}

Table 1 shows the list of arthropods associated with tomato which are dominated by insectsin the farm experimental site in the College of Agriculture, Mindanao State University, Marawi City. Dec. 2013-Feb. 2014.

Table 1 Summary of classes, order and families of arthropods associated with tomato.

\begin{tabular}{|l|l|l|l|}
\hline \multicolumn{1}{|c|}{ Class/Order } & \multicolumn{1}{|c|}{ Family } & Common Name & Scientific Name \\
\hline $\begin{array}{l}\text { Arachnida } \\
\text { 1.Araneae }\end{array}$ & $\begin{array}{l}\text { Lycosidae } \\
\text { Tetragnathidae }\end{array}$ & $\begin{array}{l}\text { Wolf spider } \\
\text { Long-jawed spider }\end{array}$ & $\begin{array}{l}\text { Lycosa sp. } \\
\text { Tetragnatha } \text { sp. }\end{array}$ \\
\hline Insecta & & & \\
\hline & & $\begin{array}{l}\text { Cabbage looper } \\
\text { Cutworm } \\
\text { Tomato fruitworm }\end{array}$ & $\begin{array}{l}\text { Trichoplusiani } \\
\text { Spodopteralitura } \\
\text { Helicoverpaarmigera }\end{array}$ \\
1. Lepidoptera & Noctuidae & Flea Beetle & Psylliodes sp. \\
\hline 2. Coleoptera & Chrysomelidae & \multicolumn{2}{|l}{} \\
\hline
\end{tabular}




\begin{tabular}{|c|c|c|c|}
\hline & $\begin{array}{l}\text { Coccinellidae } \\
\text { Curculionidae }\end{array}$ & $\begin{array}{l}\text { Squash beetle } \\
28 \text {-Spotted Lady Beetle } \\
12 \text {-spotted lady beetle } \\
\text { Snout beetle }\end{array}$ & $\begin{array}{l}\text { Aulacophorapavonana } \\
\text { Epilachnaphilippinensis } \\
\text { Epilachnachrysomelina } \\
\text { Metapocyrtus sp. }\end{array}$ \\
\hline 3. Hemiptera & $\begin{array}{l}\text { Aleyrodidae } \\
\text { Coreidae }\end{array}$ & $\begin{array}{l}\text { Whitefly } \\
\text { Leaf bug }\end{array}$ & $\begin{array}{l}\text { Bemisiatabaci } \\
\text { Unidentified sp. }\end{array}$ \\
\hline 4. Homoptera & $\begin{array}{l}\text { Aphididae } \\
\text { Cicadellidae } \\
\text { Delphacidae }\end{array}$ & $\begin{array}{l}\text { Aphids } \\
\text { Leafhopper } \\
\text { Brown planthopper }\end{array}$ & $\begin{array}{l}\text { Aphids gossipii } \\
\text { Empoasca sp. } \\
\text { Unidentified sp. }\end{array}$ \\
\hline 5. Diptera & $\begin{array}{l}\text { Agromyzidae } \\
\text { Tephritidae } \\
\text { Muscidae } \\
\end{array}$ & $\begin{array}{l}\text { Serpentine leafminer } \\
\text { Melon fruit fly } \\
\text { House fly }\end{array}$ & $\begin{array}{l}\text { Liriomyza sp. } \\
\text { Bactroceracucurbitae } \\
2 \text { unidentified spp. }\end{array}$ \\
\hline 6. Hymenoptera & $\begin{array}{l}\text { Formicidae } \\
\text { Braconidae }\end{array}$ & $\begin{array}{l}\text { Red ant } \\
\text { Parasitic wasp }\end{array}$ & $\begin{array}{l}\text { Unidentified sp. } \\
\text { Unidentified sp. }\end{array}$ \\
\hline
\end{tabular}

\section{Class Arachnida}

Spiders are the next abundant arthropods found in tomato agroecosystem aside from insects which fed on various prey species. The wolf spider,Lycosa sp. was the prevalent species found in the field (Figure 1).

\section{Class Insecta}

Tomato insects associated with tomatoes belong to 12 families under six ordersnamely Coleoptera, Diptera, Hemiptera, Homoptera , Lepidoptera, and Hymenoptera. They were categorized as phytophagous, beneficial and neutral insects.

\section{Phytophagous Insects}

The list of five insect orders that contained pest species is given in Table 2. They included Lepidoptera (tomato fruitworm, cutworm, cabbage semilooper) Coleoptera (beetle), Hemiptera (tomato mirid bug and leaf bug) Homoptera (aphids and whitefly), and Hymenoptera (ants).

Figure 1-5 are the insect pests that fed on various parts of tomatoes grown under MSU condition.

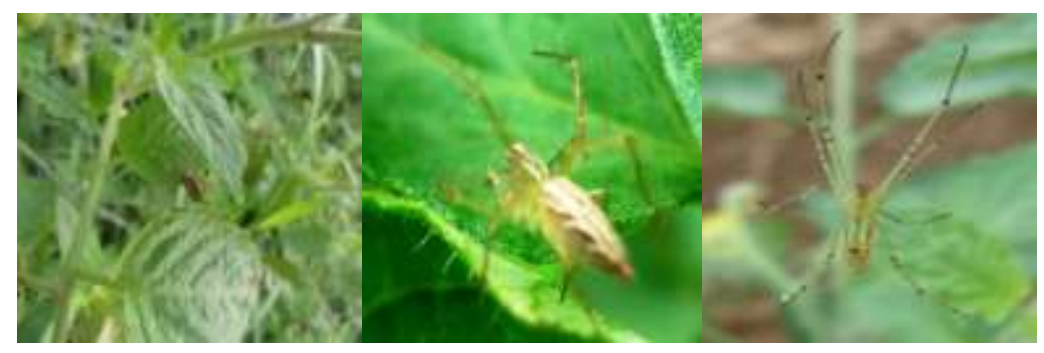

Figure 1.a. \& b.

The wolf spider, Lycosa sp. (Araneae) on tomato

$b$. an unidentified web-spinning spider 


\section{Pest that mine leaves}

a. Serpentine leafminer- Liriomyzasp. - they are colorless to bright yellow maggots which make serpentine mines in leaves (Fig. 5).

Table 2.0 List of insect pests associated with tomato plants.

\begin{tabular}{|c|c|c|c|}
\hline Class/Order & Family & Common Name & Scientific Name \\
\hline 1. Lepidoptera & Noctuidae & $\begin{array}{l}\text { Cabbage looper } \\
\text { Cutworm } \\
\text { Tomato fruitworm }\end{array}$ & $\begin{array}{l}\text { Trichoplusiani } \\
\text { Spodopteralitura } \\
\text { Helicoverpaarmigera }\end{array}$ \\
\hline 2. Coleoptera & $\begin{array}{l}\text { Chrysomelidae } \\
\text { Coccinellidae } \\
\text { Curculionidae }\end{array}$ & $\begin{array}{l}\text { Flea Beetle } \\
\text { Squash beetle } \\
\text { 28-Spotted Lady Beetle } \\
\text { 12-spotted lady beetle } \\
\text { Snout beetle }\end{array}$ & $\begin{array}{l}\text { Psylliodes sp. } \\
\text { Aulacophorapavonana } \\
\text { Epilachnaphilippinensis } \\
\text { Epilachnachrysomelina } \\
\text { Metapocyrtus sp. }\end{array}$ \\
\hline 3. Hemiptera & $\begin{array}{l}\text { Aleyrodidae } \\
\text { Coreidae }\end{array}$ & $\begin{array}{l}\text { Whitefly } \\
\text { Leaf bug }\end{array}$ & $\begin{array}{l}\text { Bemisiatabaci } \\
\text { Unidentified sp. }\end{array}$ \\
\hline 4. Homoptera & $\begin{array}{l}\text { Aphididae } \\
\text { Cicadellidae } \\
\text { Delphacidae }\end{array}$ & $\begin{array}{l}\text { Aphids } \\
\text { Leafhopper } \\
\text { Brown planthopper }\end{array}$ & $\begin{array}{l}\text { Aphids gossipii } \\
\text { Empoasca sp. } \\
\text { Unidentified sp. }\end{array}$ \\
\hline 5. Diptera & $\begin{array}{l}\text { Agromyzidae } \\
\text { Tephritidae }\end{array}$ & $\begin{array}{l}\text { Serpentine leafminer } \\
\text { Melon fruit fly }\end{array}$ & $\begin{array}{l}\text { Liriomyza sp. } \\
\text { Bactroceracucurbitae }\end{array}$ \\
\hline 6. Hymenoptera & Formicidae & Red ant & Unidentified sp. \\
\hline
\end{tabular}

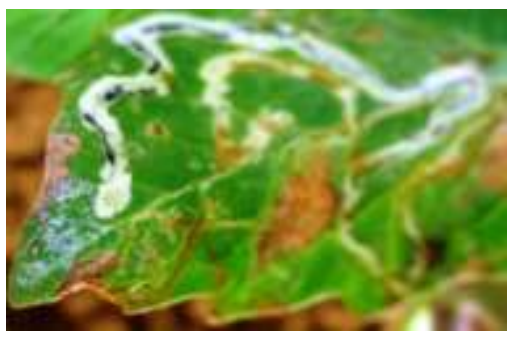

Figure 2.The serpentine tunnel made by the leafminer,Liriomyza sp.

\section{Chewing pests that make holes in leaves}

b. Cabbage looper, Trichoplusiani - Green caterpillar with longitudinal white stripes that feed on tomato leaves. Its common name islooper due to its ability to archsits back in a looping position (Fig. 5a).

c. Flea beetles, Psylliodes sp.- Tiny and shiny black colored beetle whose feeding caused tiny round holes in foliage. 
d. 12-spotted, Epilachnachrysomelina\& 28-spotted ladybird beetle Epilachnaphilippinensis ,- They are small beetles with brownish yellow forewings dotted with 12 and 28 black spots. Both adults and larvae feed on the leaves of tomato by scraping the surface of the leaves until they are skeletonized.

e. Other leaf feeding beetlesassociated with tomatoes are the squash beetle (Aulacophorapavonana), an unidentified chrysomelid beetle, and curculionid/snout beetle, Metapocyrtus sp.
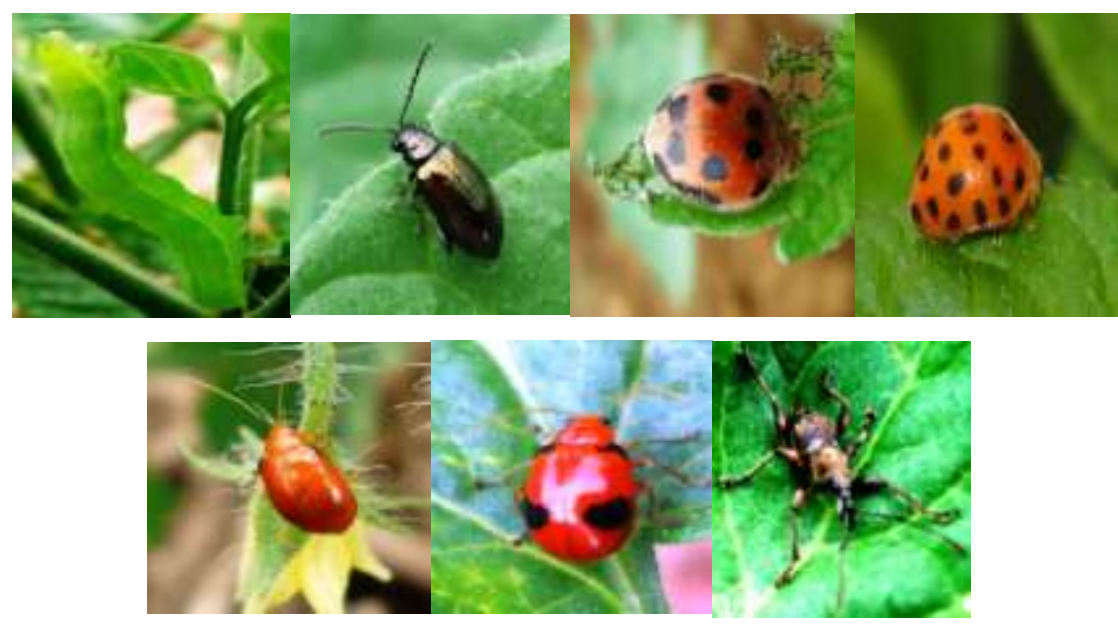

Figure 3.a. The cabbage looper, Trichoplusiani b. flea beetle, Psylliodes sp.

c. 12-spotted ladybird beetle, Epilachnachrysomelina

d. 28-spotted ladybird beetle,Epilachnaphilippinensis

e. squash beetle, Aulacophorapavonanaf. an unidentified beetle

g. curculionid beetle, Metapocyrtus sp.

\section{Sap-sucking pests which cause leaf staining, leaf or crop deformation, or defoliation}

f. Aphids, Aphis gossypii - Soft-bodied insects that feed in colonies. They excrete honeydew on which sooty mold grows thus causingleaf discoloration.

g. Tomato leafhopper,Empoascasp. Tiny winged, pale green, wedge-shaped insect that feed on the undersides of leaves.

h. Leaf-footed bug, Physomerusgrossipes- This bug has narrow cream colored stripe across the back and flattened leaf-like hind legs. It pierces plants with its needlelike mouthparts and suck sap from pods, buds, blossoms and seeds.

i. Tomato miridbug (Nesidiocoris sp.) - It is slender, greenish insect with a dark brown tint on the forewings. It feeds on stems, leaves and flowers of tomatoes. Repeated feeding by the bug cause crinkling of leaves (www.infonet-biovision.org).Predatory habits is exhibited by this bug, and has been reported preying on other insect pests, such as aphids, leafhoppers, caterpillars and whiteflies.

j. White fly, Bemiciatabaci - A tiny fly which look like a moth that suck sap from tomato plants. Like aphids, it secret honeydew hence they have similar damage.

\section{Pests that feed on fruits}

k. Cutworm - A fat, browncaterpillar which severs seedling stems near the ground and also feed on tomato fruits. It hides during the day in soil burrows at the bases of tomato plants. 
1. Tomato fruitworm, Helicoverpaarmigera. An insect whose early instars are creamcolored or yellowishgreen with few markings. Late in stars are green with pale stripes and scattered black spots on their hairy bodies. They bore holes and chewed fruits and buds. One of the most destructive insects' pests in tomato that cause a yield loss of approximately $70 \%$ due to fruit boring. They usually bore and feed on the inner parts of the fruits, causing extensive fruit damage and promoting decay caused by secondary infections (Figure 7).

m. The melon fruit fly, B. cucurbitae is commonly attracted to ripening tomatoes. The adultlaid eggs in the fresh flesh of fruits. The eggs hatch into white larvae which feed on the inside of the fruit.
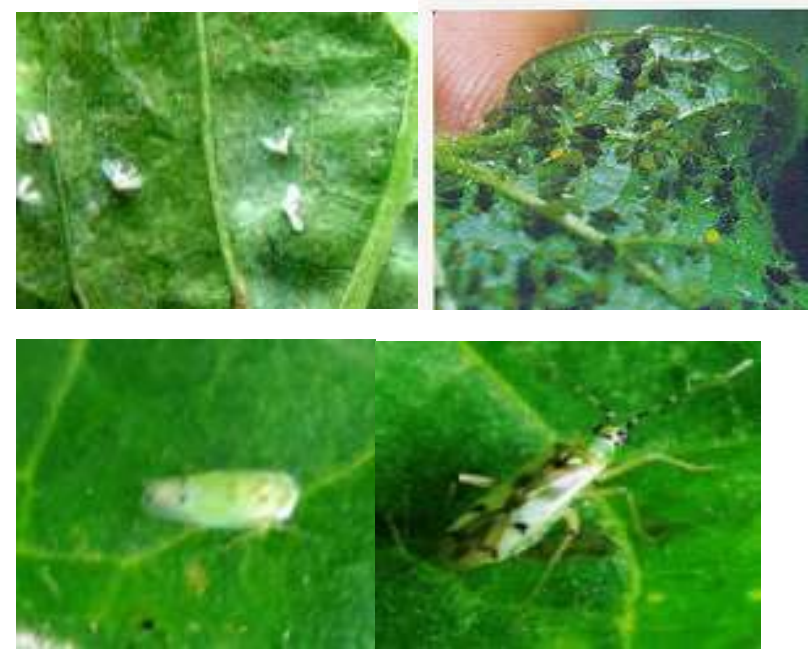

Figure 4. a. The melon aphids (Aphis gossypii) b. white fly,

Bemicia tabaci c. tomato leafhopper (Empoasca sp.)

d. leaf bug, Physomerus grossipes
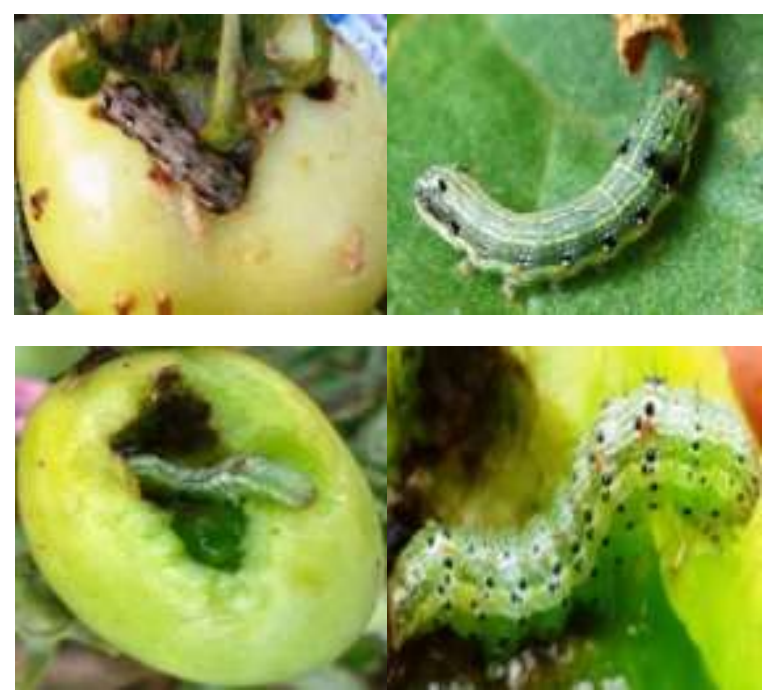

Figure 5.a\& b. The common cutworm, Spodopteralitura. $c \& d$. tomato fruitworm, Helicoverpaarmigera. 


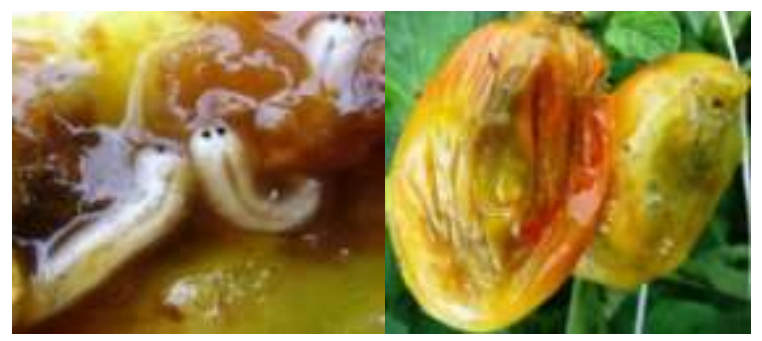

Figure 6.a. The maggots of melon fruit fly, Bactroceracucurbitae b.damaged fruits caused by the melon fruit fly

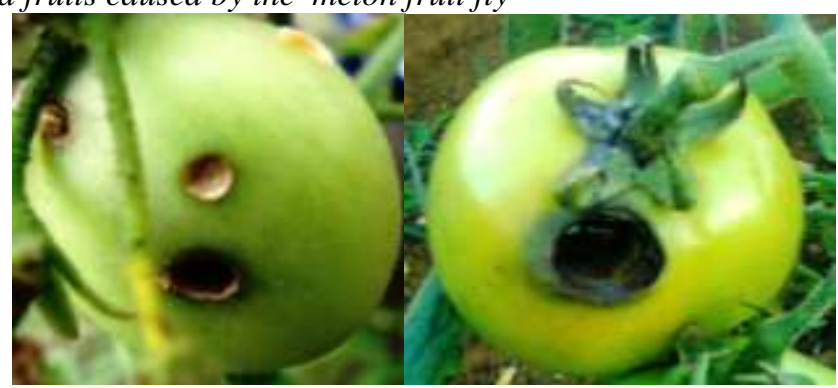

Figure 8. Damage caused by tomato fruit worm, Helicoverpaarmigera

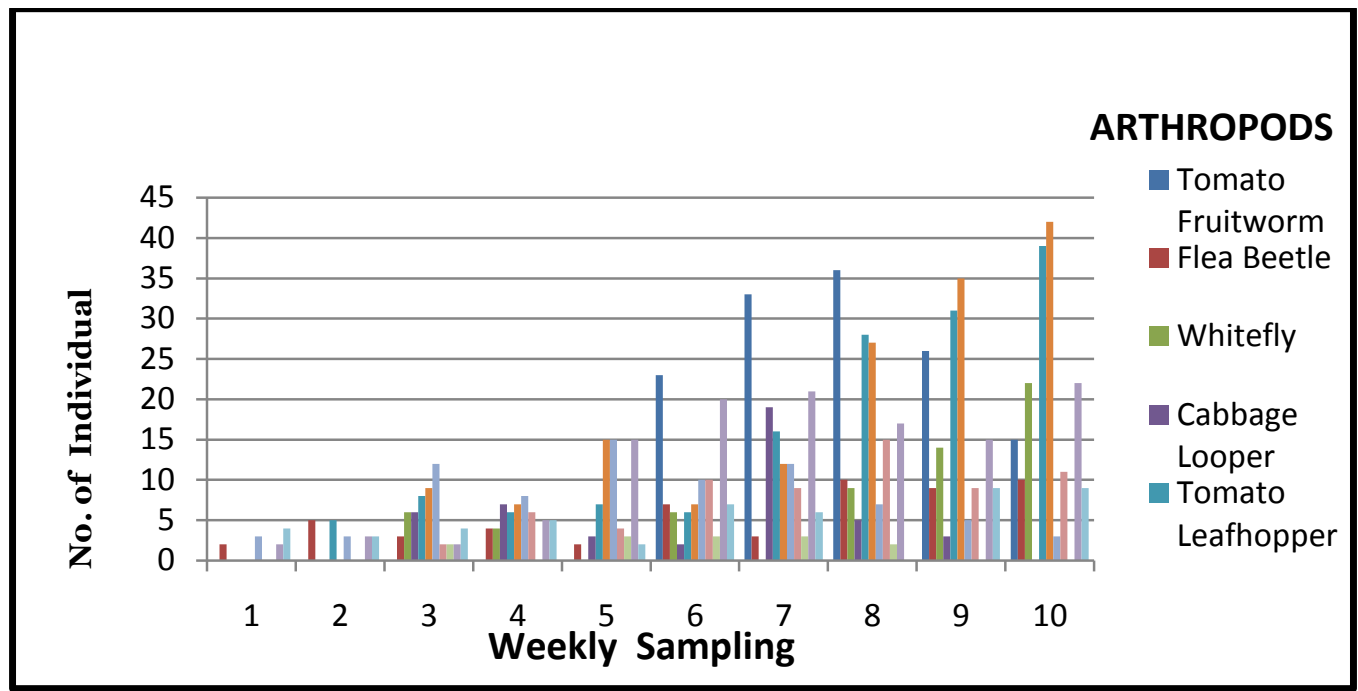

Figure 3.0 Population of insect pests and other arthropods associated with tomato.College of Agriculture, MSU, Marawi City, Lanaodel Sur, ARMM. December 14, 2013 -February 16, 2014

\section{Beneficial Insects}

Bees, ants and an unidentified braconidwasp arethe beneficialinsects foundin tomato agroecosystem. Bees helped pollinate the flowers of the tomato plants. They have a great role in ecology to prevent the extinction of each individual planted species.

Ants execute much helpful purpose in the surroundings, such as nourish on other pests (e.g., fleas, caterpillars, and termites), dead bug, and rotten tissues from deceased animals. They protect and care for honeydewproducing insects such as aphids, soft scales, whiteflies, and mealy-bugs, increasing damage from these pests. 


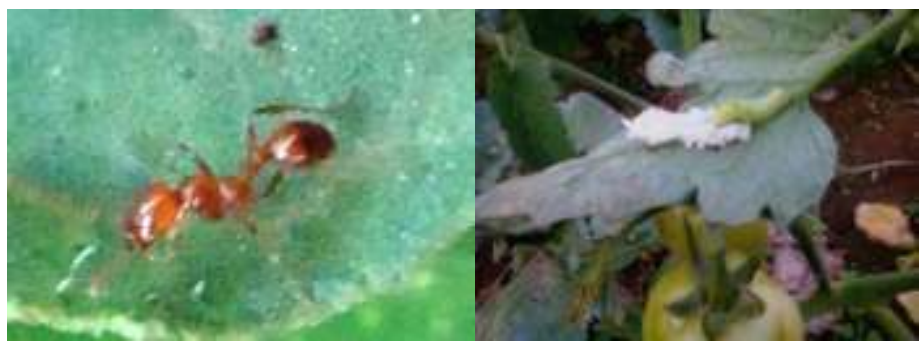

Figure 7. a. An ant b. Cocoons of parasitic wasp (Braconidae) on tomato fruitworm.

\section{Neutral Insects}

A number of house flies and muscid flies are seen in tomato agroecosystem. However, these flies are neutral insects. Adults of these insects can be predatory but they cannot do harm in the tomato plants. They can behematophagous, saprophagous, or feed on a number of types of plant and animal exudates. They can be attracted to various substances including sugar, sweat, and blood. Larvae occur in various habitats including decaying vegetation. These insects do not cause any damage to tomato plants.

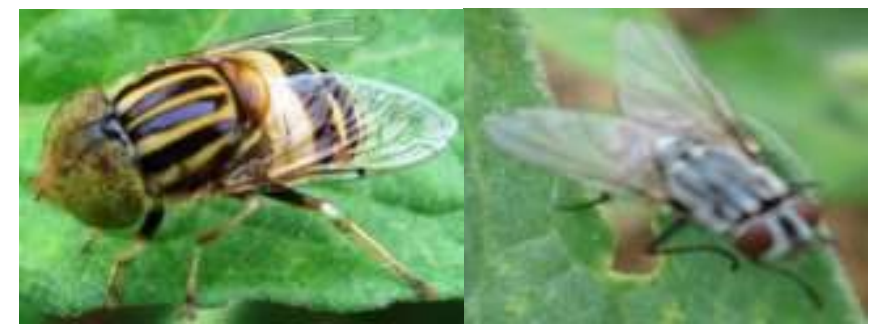

Figure 8.0 Themuscid flies (Muscidae) found on tomato plants.

According to Zeist, da Silva, de Resende, Maluf, Gabriel, Zanin and Guerra (2018) generally the main pest that attack tomato in the productive region worldwide are the biotype B whitefly Bemisiatabaci (Gennadius) (Hemiptera: Aphididae), the aphids MyzuspersicaeandMacrosiphumeuphorbiae (Thomas) (Hemiptera: Aphididae), the thripsFrankliniellaschultzei (Trybom) (Thysanoptera: Thripidae), the tomato leafminerTutaabsoluta (Meyrick) (Lepidoptera: Gelechiidae), the leafminer fly Liriomyzatrifolii (Burgess) (Diptera: Agromyzidae), the corn earworm Helicoverpazea (Boddie) (Lepidoptera: Noctuidade), the tomato fruit bearer moth Neoleucinodeselegantalis (Guenée) (Lepidoptera: Crambidae), the caterpillar H. armigera and the arachnids Tetranychusurticae (Koch) and evansi(Baker; Pritchard) (Acari: Tetranychidae). They said that it is better to use alternative way in minimizing the problems of arthropods/pest arising from agrochemical application and maintaining pest populations below economic damage level through application of agricultural biotechnology which is the development of tomato plant that is resistance to insects and arachnid pests. Gil (2015) said that the community of arthropod associated to pests in tomato is broad. Numerous species of aphids, white flies, thrips, lepidoptera, coleoptera, diptera and some mite species are very common among them.

\section{Conclusion and Recommendation}

Based on the findings of thesurvey arthropods associated with tomatoes belong to Class Insectaand ClassArachnida. The most dominant arthropods were the insects while Lycosa sp. was the dominat spider present in tomato plants. The insects in tomatoes consistedof 18 families under six order namely, Lepidoptera, Coleoptera, Hemiptera, Homoptera, Diptera and Hymenoptera. They were classified as phytophagous, beneficial, and neutral insects. 
Insect pests of tomatoes included theleafminer,Liriomyza sp., cabbage looper, Trichoplusiani, cutworm , Spodopteralitura, tomato fruitworm , Helicoverpaarmigera, flea beetle , Psylliodes sp., 12-spotted ladybird beetle , Epilachnachrysomelina, 28-spotted ladybird beetle,Epilachnaphilippinensis, squash beetle,Aulacophorapavonana, an unidentified chrysomelidbeetle, curculionid beetle, Metapocyrtus sp.melon aphids, Aphis gossypii, white fly, Bemicia tabaci, tomato leafhopper, Empoasca sp., an unidentified leaf bug and melon fruit fly, Bactroceracucurbitae. Thetomato fruitworm, $H$. armigerawas the major insect pest oftomatoes under Lanao del Sur condition. Visual counts consistently showed a high larval population of this pest throughout the conduct of this study.

Beneficial insects that belong to order Hymenoptera were the bees, ants and an unidentified braconid wasp. They play important role in reducing the insect pest population in tomatoes together with the spiders. Neutral insects consisted of house flies which do not cause any damage to tomatoes. It is recommended further studies be conducted including the life cycle of tomato fruitworm, H. armigera.

\section{References}

[1] Gil, M. A. (2015). Insect Resistance In Tomato (Solanum spp.).DOI: 10.13140/RG.2.2.3

[2] HorticulturaBrasileira (2009). Hortic.Bras. vol.27 no.3 Brasília Print version ISSN 0102-0536 http://dx.doi.org/10.1590/S0102-05362009000300007

[3] Kund, G.S., Carson, W.G., and Trumble, J.T. (2015).Arthropod Management Tests, Volume 40, Issue 1, December 2015, E18,https://doi.org/10.1093/amt/tsv076

[4] Lange, W.H. and L. Bronson (1981).Insect pests of tomatoes. Ann. Rev. Entomol. 26:345-31.

[5] Morandina, L.A., Long, R.F. and Kremena, C. (2014). Agriculture, Ecosystems and Environment.Published by Elsevier B.V.

[6] Wakil, W., Brust, G. and Perring, T. (2017). Arthropod Pests of Tomato. $1^{\text {st }}$ Edition eBook ISBN: 9780128135082, Paperback ISBN: 9780128024416, Academic Press

[7] Wakil, W., Brust, G. and Perring, T.(2017). Sustainable management of arthropod pests of tomato.

[8] Zeist, da Silva, de Resende, Maluf, Gabriel, Zanin and Guerra (2018).Tomato Breeding for Insect-Pest Resistance. DOI: 10.5772/intechopen.75978. 